\title{
Reviewer Acknowledgements for Global Journal of Health Science, Vol. 13, No. 2
}

Global Journal of Health Science wishes to acknowledge the following individuals for their assistance with peer review of manuscripts for this issue. Their help and contributions in maintaining the quality of the journal are greatly appreciated.

Global Journal of Health Science is recruiting reviewers for the journal. If you are interested in becoming a reviewer, we welcome you to join us. Please contact us for the application form at: gjhs@ccsenet.org.

\section{Reviewers for Volume 13, Number 2}

Angel Alfonso Velarde Lopez, University of Pennsylvania, Guatemala

António Calha, Polytechnic Institute of Portalegre, Portugal

Ayesha Johnson, University of South Florida, United States of America

David John Lindsay, James Cook University, Australia

David Otieno Odongo, Masinde Muliro University of Science and Technology, Kenya

Evanthia Sakellari, Technological Educational Institute of Athens, Greece

Farahnaz Amini, UCSI University, Malaysia

Fengsong Gao, The University of Queensland, Australia

Francisco Rodenas Rigla, University of Valencia, Spain

Gabriel Gulis, University of Southern Denmark, Denmark

Gabriele Messina, University of Siena, Italy

Gavric Zivana, University Banja Luka, Bosnia and Herzegovina

Georgann Valerie Weissman, Capella University, United States of America

Hadii M Mamudu, East Tennessee State University, United States of America

Kartheek R Balapala, University Tunku Abdul Rahman, Malaysia

Kim Solez, University of Alberta, Canada

Liye Suo, The Ohio State University, United States of America

Loray Daws, British Columbia Masterson Institute, Canada

Marcel Wullschleger, University of Bern, Switzerland

Meng Zhao, Texas A\&M University at Corpus Christi, United States of America

Raywat Deonandan, University of Ottawa, Canada

Samir Othman, Hawler Medical University, Iraq

Thanusin Saleeon, Ministry of Public Health, Thailand

Valery Piacherski, Mogilev Regional Hospital, Belarus 